\title{
Effect of Hydrogel-Based Antibiotic Intracanal Medicaments on Push-Out Bond Strength
}

\author{
Rayan B. Yaghmoor ${ }^{1,2}$ Jeffrey A. Platt ${ }^{2}$ Kenneth J. Spolnik ${ }^{3}$ Tien Min Gabriel Chu² Ghaeth H. Yassen ${ }^{2,4}$
}

\footnotetext{
${ }^{1}$ Department of Restorative Dentistry, College of Dental Medicine, Umm Al-Qura university, Makkah, Saudi Arabia

2Department of Biomedical Sciences and Comprehensive Care, Indiana University School of Dentistry, Indianapolis, Indiana, United States

${ }^{3}$ Department of Endodontics, Indiana University School of Dentistry, Indianapolis, Indiana, United States

${ }^{4}$ Department of Endodontics, Case School of Dental Medicine, Cleveland, Ohio, United States
}

Eur J Dent:2020;14:575-583

\begin{abstract}
Address for correspondence Rayan Bahjat Yaghmoor, BDS, MSD, Department of Restorative Dentistry, College of Dental Medicine, Umm Al-Qura university, 2373 Al Awali, Makkah 24381, Saudi Arabia (e-mail: rbyaghmoor@uqu.edu.sa).
\end{abstract}

\begin{abstract}
Keywords

- bond strength

- intracanal medicaments

- regenerative endodontics

Objective This study aimed to evaluate the effects of typical clinical concentration $(1,000 \mathrm{mg} / \mathrm{mL})$, low concentration $(1 \mathrm{mg} / \mathrm{mL})$ triple antibiotic pastes (TAP), and double antibiotic pastes (DAP) on the bond strength between various root cements and radicular dentin.

Materials and Methods Intact single-rooted human teeth $(n=144)$ were horizontally decoronated and canals instrumented. The roots were treated for 4 weeks with $\mathrm{Ca}(\mathrm{OH})_{2}, 1,000 \mathrm{mg} / \mathrm{mL}$ of TAP or DAP, and $1 \mathrm{mg} / \mathrm{mL}$ of TAP or DAP. Untreated roots served as a control. After treatment, the medicaments were irrigated and each group was divided into three subgroups receiving MTA, Biodentine, or Endosequence putty cement. After 2 weeks, coronal and middle root cylinders were obtained from each root. Push-out bond strength test and failure analysis were performed for all root cylinders.

Statistical Analysis Three-way ANOVA, pairwise comparisons and logistic regression were used for statistical analyses. A significance level of $5 \%$ was used.

Results For MTA applied in the coronal part of the roots, $1 \mathrm{mg} / \mathrm{mL}$ DAP and TAP and $\mathrm{Ca}(\mathrm{OH})_{2}$ demonstrated significantly higher bond strength compared with the typical clinical concentration and the control groups. For Biodentine applied coronally in the roots, $1 \mathrm{mg} / \mathrm{mL}$ of DAP resulted in significantly higher bond strength than all other groups. For Endosequence putty cement applied coronally in the roots, $1 \mathrm{mg} / \mathrm{mL}$ of DAP offered significantly higher bond strength than all groups except for $\mathrm{Ca}(\mathrm{OH})_{2}$.

Conclusion The use of $1 \mathrm{mg} / \mathrm{mL}$ DAP resulted in significantly higher push-out bond strength compared with the typical clinical concentration of TAP and DAP regardless of the type of the root cement used.
\end{abstract}

\section{Introduction}

Various treatment approaches have been proposed to manage immature teeth with pulpal necrosis. The most contemporary treatment option for these teeth is endodontic regeneration (ER), which depends on the efficient disinfection of the root canal. ${ }^{1}$ The intracanal disinfection usually is accomplished via irrigation solutions and intracanal medicaments. ${ }^{2}$ Numerous intracanal medicaments have been proposed for ER treatment, such as $\mathrm{Ca}(\mathrm{OH})_{2}{ }^{3}$ triple antibiotic paste (TAP) (equal amounts of metronidazole, ciprofloxacin, and 
minocycline), ${ }^{4}$ and double antibiotic paste (DAP) (equal parts of metronidazole and ciprofloxacin). ${ }^{5}$ Furthermore, lower concentrations of DAP and TAP ranging from 1 to $5 \mathrm{mg} / \mathrm{mL}$ have been recommended by the American Association of Endodontists (AAE) ${ }^{6}$ to minimize the harmful biological effects of these medicaments on stem cells from apical papillae. $^{7}$

The effects of different intracanal medicaments on the mechanical and surface properties of the radicular dentin have been investigated.8,9 One of the studies found that $1 \mathrm{mg} / \mathrm{mL}$ of TAP and $\mathrm{Ca}(\mathrm{OH})_{2}$ had significantly less effect on microhardness and superficial demineralization of radicular dentin compared with $1,000 \mathrm{mg} / \mathrm{mL}^{2}$ TAP. ${ }^{8}$ Yassen et al supported this finding, where $1,000 \mathrm{mg} / \mathrm{mL}$ TAP and DAP resulted in significantly less microhardness than $\mathrm{Ca}(\mathrm{OH})_{2} \cdot{ }^{9}$ In the same study, root cylinders treated with TAP showed higher fracture resistance compared with DAP and $\mathrm{Ca}(\mathrm{OH})_{2}$ after 3 months of application. ${ }^{9}$ Recent studies found that the type of intracanal medicaments may have an impact on the bond strength of intracanal cements to radicular dentin. ${ }^{10,11}$ Recent studies reported significant negative effects of $\mathrm{Ca}(\mathrm{OH})_{2}{ }^{12}$ as well as typical clinical concentrations of DAP ${ }^{10,12}$ and TAP ${ }^{12}$ on bond strength of calcium silicate-based cements to root dentin. On the other hand, Topçuoğlu et al showed in their study that $\mathrm{Ca}(\mathrm{OH})_{2}$ and TAP did not significantly compromise the bond strength of root cements to dentin. ${ }^{10}$ Nevertheless, limited studies reported using low concentrations of DAP or TAP to evaluate its effect on bond strength of root cements, as it is technically impossible to maintain the liquid form of low antibiotic concentrations within the root canal over an extended period of time. Multiple recent studies introduced low concentrations of DAP and TAP loaded in a methylcellulose hydrogel system. These low antibiotic concentrations offer superior antibacterial properties ${ }^{13}$ and comparable biocompatibility to $\mathrm{Ca}(\mathrm{OH})_{2} \cdot{ }^{14}$ The ability of loading low concentrations of DAP and TAP into a methylcellulose hydrogel system would enable us to estimate the effect of these low concentrations on bond strength of various calcium-silicate cements.

Calcium silicate-based cements have been used widely in ER treatment. Moreover, Calcium silicate-based cements have favorable properties (such as biocompatibility, ability to kill bacteria, sealing ability, bioactivity, ability to set in a moist environment, and acceptable mechanical and physical properties) that make it the material of choice in ER. ${ }^{15,16}$ This study aimed to evaluate the effects of low concentrations of TAP and DAP ( $1 \mathrm{mg} / \mathrm{mL}$ ) loaded into a methylcellulose hydrogel system on push-out bond strength of various calcium silicate-based root cements.

\section{Materials and Methods}

\section{Sample Preparations}

Intact, single, straight, and conical-rooted human teeth ( $n=144$ ) were selected for this study according to local university institutional review board (IRB) guidelines (IRB 1408889870). The teeth were saved for a maximum of 6 months after extraction at $4^{\circ} \mathrm{C}$ in $0.1 \%$ thymol solution until used. Samples were horizontally decoronated $0.5 \mathrm{~mm}$ apical to the facial/buccal cementoenamel junction using a water-cooled low-speed diamond saw (Buehler Ltd.; Lake Bluff, IL, USA Illinois, United States). Furthermore, the apical $3 \mathrm{~mm}$ of each root were removed, resulting in $8 \pm 1 \mathrm{~mm}$ root sections. The internal diameter of the roots was standardized by mechanical preparation with Peeso reamers (Dentsply; Johnson City, Tennessee, United States) (size 1-5) to a final diameter of $1.5 \mathrm{~mm}$. After the use of each size of Peeso reamer, root canals were irrigated with $2 \mathrm{~mL}$ of $1.5 \%$ sodium hypochlorite $(\mathrm{NaOCl})$ for 1 minute using a 27-gauge needle. After instrumentation was completed, each canal received a final rinse with $5 \mathrm{~mL}$ of $1.5 \% \mathrm{NaOCl}$ for 2 minutes, $5 \mathrm{~mL}$ of $17 \%$ ethylenediaminetetraacetic acid (EDTA) (Vista; Racine, Tennessee, United States) for 2 minutes and $5 \mathrm{~mL}$ of sterile water for 2 minutes.

\section{Intracanal Medicament Preparation}

Intracanal medicaments were prepared based on previously published studies. ${ }^{8,17}$ For the typical clinical concentration of TAP, 1,000 mg of United States Pharmacopeia grade antibiotic powders compounded of equal portions of metronidazole, ciprofloxacin, and minocycline (Champs Pharmacy; San Antonio, Texas, United states) were mixed with $1 \mathrm{~mL}$ of sterile water. The same was performed to prepare the typically used clinical concentration of DAP but without adding the minocycline. To prepare low concentrations of antibiotic medicaments, $100 \mathrm{mg}$ TAP or DAP powders were dissolved in $100 \mathrm{~mL}$ of sterile water. After that, $8 \mathrm{~g}$ of methylcellulose powder (Methocel 60 HG; Sigma-Aldrich, St. Louis, Missouri, United Station) were progressively added to the $100 \mathrm{~mL}$ of $1 \mathrm{mg} / \mathrm{mL}$ solution of TAP or DAP and mixed for 60 minutes with the aid of a magnetic stir bar to produce a final homogeneous paste with $1 \mathrm{mg} / \mathrm{mL}$ concentration of TAP or DAP. The methylcellulose system increased the viscosity of the low concentration TAP or DAP to make its consistency clinically applicable. Commercial $\mathrm{Ca}(\mathrm{OH})_{2}$ intracanal dressing was also used (UltraCal XS; Ultradent, South Jordan, Utah, United States).

\section{Treatment Procedure}

The prepared roots were randomly divided into six treatment groups according to the type and concentration of intracanal medicament ( $n=24$ per group): no-treatment control group, $\mathrm{Ca}(\mathrm{OH})_{2}$, typical clinical concentration of TAP $(1,000 \mathrm{mg} / \mathrm{mL})$, low concentration TAP loaded into a methylcellulose system (1 mg/mL), typical clinical concentration DAP $(1,000 \mathrm{mg} / \mathrm{mL})$, and low concentration DAP loaded into a methylcellulose system (-Fig. 1).

Intracanal medicaments $(0.05 \mathrm{~mL})$ were injected into the root canals in their respective groups using the 1-mL disposable syringes (BD; Franklin Lakes, New Jersey, United States) and intracanal capillary tips (Ultradent). After extrusion of the intracanal medicament from the apical opening, excess was removed and apical openings as well as the coronal access were sealed using a light cure flowable composite (Kerr; Orange, California, United States). The flowable composite was bonded by a one-step self-etch adhesive bonding agent (G-aenial; GC, Alsip, Illinois, United States) on the external surface of the root with extreme caution to avoid 


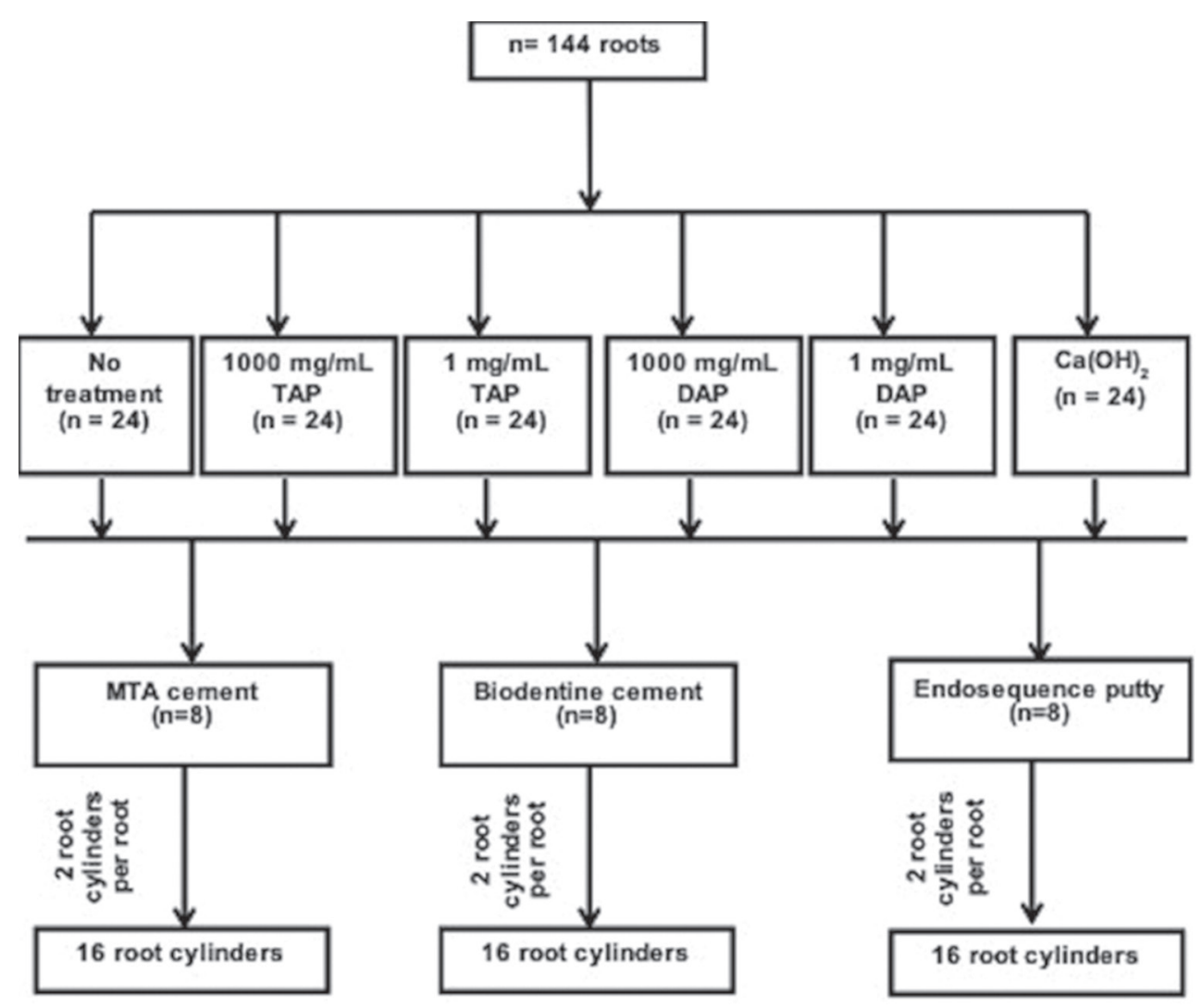

Fig. 1 Schematic illustration of the experimental groups used in the study and the type of medicaments and/or intracanal cements used in each group. $\mathrm{Ca}(\mathrm{OH})_{2}$, calcium hydroxide; DAP, double antibiotic paste; TAP, triple antibiotic paste.

touching the internal wall of the radicular dentin. Roots were incubated in deionized water at $37^{\circ} \mathrm{C}$ for 4 weeks. The 4 -week application period reflected the current clinical guidelines of ER procedures recommended by the AAE. ${ }^{6}$

After incubation, roots treated with each intracanal medication were randomized into three subgroups based on type of root cement ( $8=$ per subgroup): mineral trioxide aggregate (MTA) cement (Proroot; Dentsply, Tulsa, Oklahoma, United States), Biodentine cement (Septodont; Sant-Maurdes-Fosses, France), and Endosequence putty cement (Putty, Endosequence, Savannah, Georgia). The roots were reaccessed, and each root canal was irrigated with $5 \mathrm{~mL}$ (17\%) EDTA followed by $5 \mathrm{~mL}$ of sterile water to remove the intracanal dressing. Each of the three cements was mixed according to the manufacturer's instructions and applied into roots with different sizes of endodontic pluggers. The roots were then resealed with flowable composite and stored in a humid environment at $37^{\circ} \mathrm{C}$ for 2 weeks to ensure the complete setting of the calcium silicate cements. Conventional radiographs were taken buccolingually and mesiodistally to evaluate the compactness of the intracanal cement. After incubation, two cylindrical cross-sections with $1.5 \mathrm{~mm}$ thickness were coronally obtained from each root using a water-cooled diamond saw. The apical- and coronal- sealed areas of the roots were excluded from the root cylinders. Root canal diameters and the thickness of each root cylinder were measured to the nearest $0.01 \mathrm{~mm}$ utilizing a digital caliper (Mitutoyo, Japan). The area of adhesion between the cement and each root cylinder was estimated according to the following equation:

$$
\text { Adhesion surface area }\left(\mathrm{mm}^{2}\right)=\frac{(D 1+D 2)}{2 \times \pi \times h}
$$

where D1 and D2 are coronal and apical cylinder diameters, respectively, $\pi$ is the constant 3.14 , and $h$ is the thickness of the root cylinder.

\section{Push-Out Bond Strength Test}

This test was conducted utilizing by a universal testing machine (Sintech Renew 1123; MTS, Eden Prairie, Minnesota, United States) as described in a previous study. ${ }^{18}$ The root cylinders were stabilized, with the apical side facing upward, on the center of a metal disc that had a central hole ( - Fig. 2 ). The central hole within the metal disc was larger than the root cylinder's internal diameter to maintain the root cylinder in the correct position while allowing easy dislodgment of the root cement. A compressive force was applied at a crosshead speed of $0.5 \mathrm{~mm} / \mathrm{min}$ using a cylindrical metal plunger $(1.3 \mathrm{~mm}$ in diameter) connected to the load cell $(2,500 \mathrm{~N})$. The metal plunger diameter was smaller than the internal root diameter by approximately $0.2 \mathrm{~mm}$. The force of dislodgement of the dental cements was reported in newtons, and the push-out bond strength (megapascal [MPa]) was computed for all samples using the equation below: 


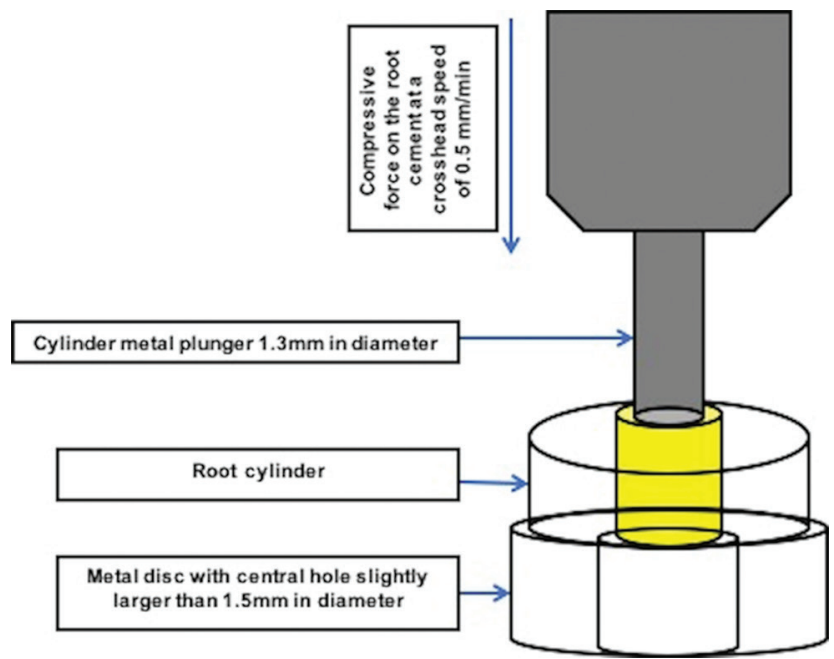

Fig. 2 Representative drawing shows: root cylinder sample fixed on the metal disc for the push-out bond strength test.

Push out bond strength $(\mathrm{MPa})=\frac{\text { the dislodgment force }(\mathrm{N})}{\text { adhesion surface } \operatorname{area}\left(\mathrm{mm}^{2}\right)}$

Following the push-out experiment, the failure pattern of each sample was inspected using stereomicroscopy (Nikon UM-2; Tokyo, Japan) at $\times 40$ magnification and classified according to the following criteria: (1) adhesive failure (between dentin and the root cement), (2) cohesive failure (within the root cement), or (3) mixed failure.

\section{Statistical Analysis}

Bond strength was evaluated using three-way ANOVA with factors for cements (MTA, Biodentine and Endosequence putty), treatment (Control, $\mathrm{Ca}(\mathrm{OH})_{2}, 1,000 \mathrm{mg} / \mathrm{mL} \mathrm{TAP}$, $1 \mathrm{mg} / \mathrm{mL}$ TAP, $1,000 \mathrm{mg} / \mathrm{mL}$ DAP, and $1 \mathrm{mg} / \mathrm{mL}$ DAP) and location on the root (coronal and middle), as well as all two-way and three-way interactions among the factors. All pairwise comparisons from ANOVA were made using least significant differences to control the overall significance level at 5\% (only the significant interactions were included). Generalized estimating equation methodology for cumulative logistic regression was used to evaluate the effects of cement type, treatment, and location on failure mode; two-way and threeway interactions were included in the model. The statistical significant level was at $5 \%$.

\section{Results}

Three-way ANOVA showed that all three variables (location, cement, and intracanal medicament) had a significant effect on bond strength (all $p<0.0001$ ). Moreover, the two-way interactions between previously mentioned factors showed a significant difference in bond strength with (intracanal medicament $\times$ cement $)(p<0.0001)$ and (intracanal medicament $\times$ location $)(p<0.0002)$, but no significant difference with (cement interacted $\times$ location) $(p>0.05)$. However, the three-way interactions between all three variables revealed no significant difference
( $p>0.05)$. All treatment groups had significantly higher bond strength in the coronal root cylinders than the middle root cylinders $(p<0.0003)$ except for $1,000 \mathrm{mg} / \mathrm{mL}$ DAP, which had no significant difference between the coronal and middle root cylinders $(p>0.05)$ ( - Figs. 3-5).

When $1 \mathrm{mg} / \mathrm{mL}$ DAP was used, Biodentine had significantly higher bond strength than MTA $(p<0.0001)$ and Endosequence putty $(p<0.04)$ (-Figs. 6 and 7). Furthermore, Endosequence putty had significantly higher bond strength than MTA ( $p=0.0044)$ (-Figs. 6 and 7). However, $\mathrm{Ca}(\mathrm{OH})_{2}$ and $1 \mathrm{mg} / \mathrm{mL}$ TAP groups demonstrated no significant difference between all three types of cements $(p>0.05)$ (-Figs. 6 and 7). The $1,000 \mathrm{mg} / \mathrm{mL}$ TAP and DAP

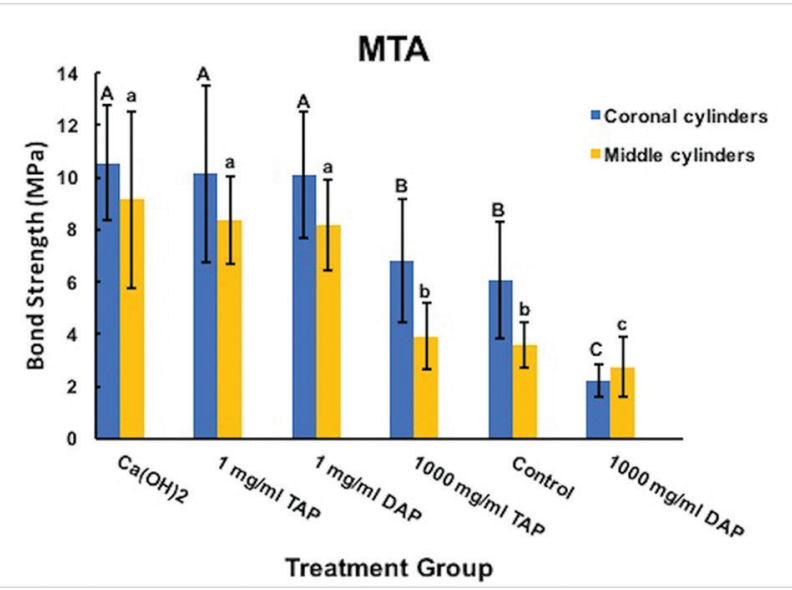

Fig. 3 Mean \pm standard deviation of the push-out bond strength (megapascals) of mineral trioxide aggregate cement in the coronal and middle cylinders when using different treatments. Different uppercase letters represent significant differences between different types of treatments in coronal cylinders. Different lowercase letters represent significant differences between different types of treatments in middle cylinders.

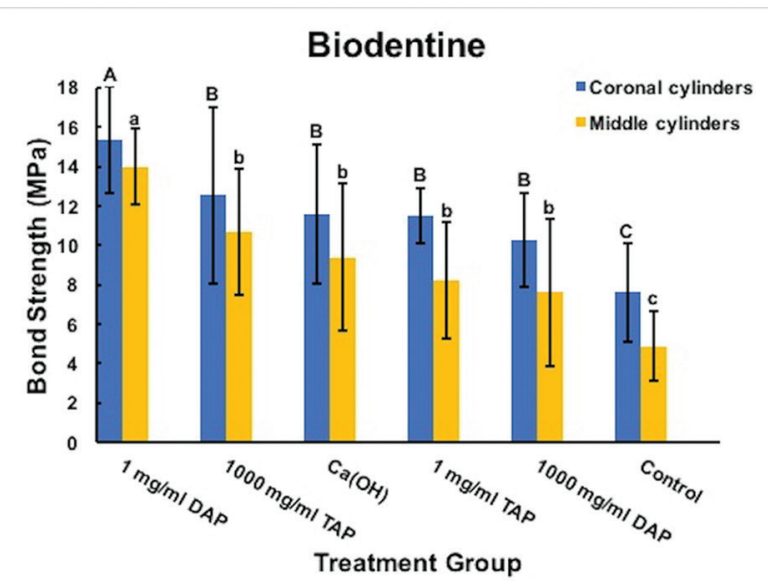

Fig. 4 Mean \pm standard deviation of the push-out bond strength (megapascals) of Biodentine cement in the coronal and middle cylinders when using different treatments. Different uppercase letters represent significant differences between different types of treatments in coronal cylinders. Different lowercase letters represent significant differences between different types of treatments in middle cylinders. 


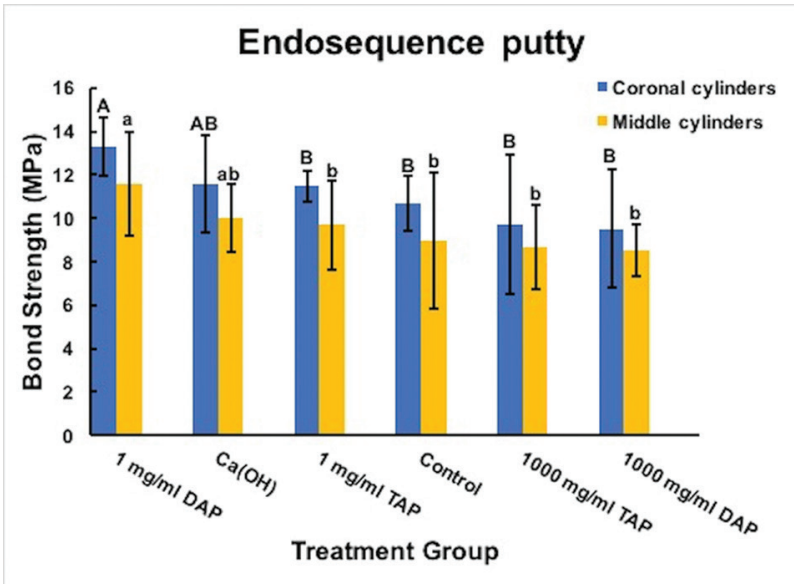

Fig. 5 Mean \pm standard deviation of the push-out bond strength (megapascals) of Endosequence putty cement in the coronal and middle cylinders when using different treatments. Different uppercase letters represent significant differences between different types of treatments in coronal cylinders. Different lowercase letters represent significant differences between different types of treatments in middle cylinders.

\section{Coronal root cylinders}

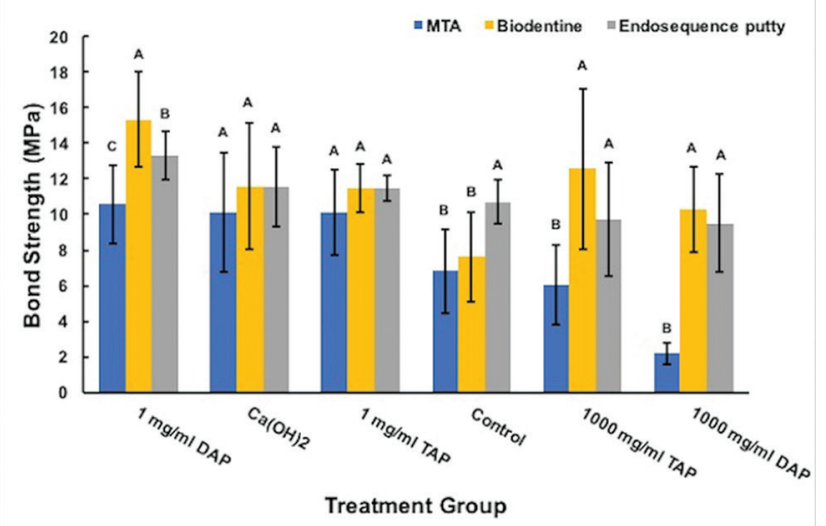

Fig. 6 Mean \pm standard deviation of the push-out bond strength (megapascals) of the cements used in the coronal root cylinders when using different treatments. Different uppercase letters represent significant differences between different types of cements.

groups displayed the same bond strength trend between the three cements as follows: Endosequence putty and Biodentine were significantly higher than MTA (all $p<0.0001$ ) but did not show a significant difference between each other $(p>0.05)$ ( - Figs. 6 and 7). Finally, the control group revealed that the Endosequence putty had significantly higher bond strength than MTA $(p<0.0001)$ and Biodentine $(p<0.002)$, but not between MTA and Biodentine $(p>0.05)$ ( $~-$ Figs. 6 and $\mathbf{7}$ and - Table $\mathbf{1}$ ).

When MTA was used, $\mathrm{Ca}(\mathrm{OH})_{2}, 1 \mathrm{mg} / \mathrm{mLDAP}$, and TAPgroups had significantly higher bond strength than $1,000 \mathrm{mg} / \mathrm{mL}$ TAP and control groups (all $p<0.0002$ ). Additionally, $1,000 \mathrm{mg} / \mathrm{mL}$ DAP group had significantly lower bond
Middle root cylinders

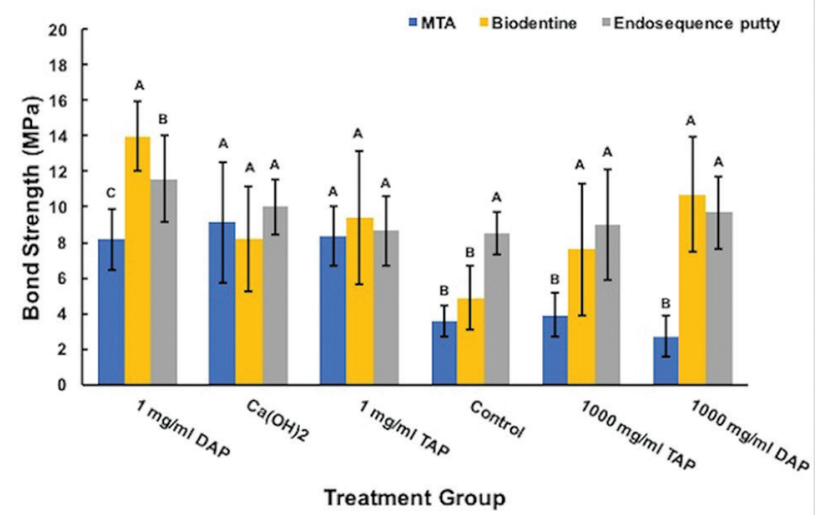

Fig. 7 Mean \pm standard deviation of the push-out bond strength (megapascals) of the cements used in the middle root cylinders when using different treatments. Different uppercase letters represent significant differences between different types of cements.

strength than all other groups (all $p<0.01$ ) ( - Fig. 3). When Biodentine was used, $1 \mathrm{mg} / \mathrm{mL}$ DAP group had significantly higher bond strength than all other medicament-containing groups (all $p<0.0001$ ). Furthermore, the control group had significantly lower bond strength than all other groups (all $p<0.0008)(-$ Fig. 4). When Endosequence putty was used, $1 \mathrm{mg} / \mathrm{mL}$ DAP group demonstrated significantly higher bond strength than all groups (all $p<0.03$ ) except the $\mathrm{Ca}(\mathrm{OH})_{2}$ group $(p>0.05)(-$ Fig. 5 and $\boldsymbol{- T a b l e ~} \mathbf{1})$.

The coronal location had significantly higher proportion of cohesive failures than the middle location for: Biodentine cement in the control group ( $p=0.0137$ ), MTA cement in the $1,000 \mathrm{mg} / \mathrm{mL}$ DAP $(p=0.0497)$, and $1 \mathrm{mg} / \mathrm{mL}$ TAP groups $(p=0.0026)$. The coronal location had significantly lower proportion of cohesive failures than the middle location for MTA cement in the $1 \mathrm{mg} / \mathrm{mL}$ DAP group $(p=0.0003)$ (-Table 2 ). MTA had significantly lower proportion of cohesive failures than Endosequence putty and Biodentine for the $1 \mathrm{mg} / \mathrm{mL}$ DAP group at the coronal location $(p<0.03)(-$ Table 2$)$.

The $1 \mathrm{mg} / \mathrm{mL}$ DAP group had significantly higher proportion of cohesive failures than the control $(p=0.0417)$ and $1,000 \mathrm{mg} / \mathrm{mL}$ TAP $(p=0.0247)$ groups for Endosequence putty at coronal and middle locations. The $1 \mathrm{mg} / \mathrm{mL}$ DAP group had significantly lower proportion of cohesive failures than the $1,000 \mathrm{mg} / \mathrm{mL}$ DAP $(p=0.0066), 1 \mathrm{mg} / \mathrm{mL}$ TAP $(p>0.0279)$, and $1,000 \mathrm{mg} / \mathrm{mL}$ TAP $(p>0.0123)$ groups for MTA at the coronal location. The control group had significantly lower proportion of cohesive failures than the $1,000 \mathrm{mg} / \mathrm{mL}$ DAP and $1 \mathrm{mg} / \mathrm{mL}$ TAP groups for Endosequence putty at the middle location (all $p=0.03$ ). Additionally, the control group had significantly lower proportion of cohesive failures than the $1 \mathrm{mg} / \mathrm{mLTAP}(p=0.03)$ group for Biodentine at the middle location ( - Table 2 ). 
Table 1 Mean \pm standard deviation of the push-out bond strength (megapascals) in coronal and middle root cylinders

\begin{tabular}{|c|c|c|c|c|c|c|}
\hline Treatment & \multirow[t]{2}{*}{ Control } & \multirow[t]{2}{*}{$\mathrm{Ca}(\mathrm{OH})_{2}$} & \multirow{2}{*}{$\begin{array}{l}1,000 \mathrm{mg} / \mathrm{mL} \\
\text { TAP }\end{array}$} & \multirow[t]{2}{*}{$1 \mathrm{mg} / \mathrm{mL}$ TAP } & \multirow{2}{*}{$\begin{array}{l}1,000 \mathrm{mg} / \mathrm{mL} \\
\text { DAP }\end{array}$} & \multirow[t]{2}{*}{$1 \mathrm{mg} / \mathrm{mL}$ DAP } \\
\hline Cement & & & & & & \\
\hline \multicolumn{7}{|c|}{ Coronal } \\
\hline MTA & $6.81(2.4)^{\mathrm{B}, \mathrm{b}}$ & $10.14(3.4)^{\mathrm{A}, \mathrm{a}}$ & $6.04(2.2)^{\mathrm{B}, \mathrm{b}}$ & $10.12(2.4)^{\mathrm{A}, \mathrm{a}}$ & $2.22(0.6)^{\mathrm{B}, \mathrm{C}}$ & $10.56(2.2)^{\mathrm{c}, \mathrm{a}}$ \\
\hline Biodentine & $7.63(2.5)^{B, C}$ & $11.59(3.5)^{\mathrm{A}, \mathrm{b}}$ & $12.55(4.5)^{\mathrm{A}, \mathrm{b}}$ & $11.47(1.4)^{\mathrm{A}, \mathrm{b}}$ & $10.26(2.4)^{A, b}$ & $15.34(2.7)^{A, a}$ \\
\hline Endosequence putty & $10.7(1.3)^{A, b}$ & $11.58(2.2)^{\mathrm{A}, \mathrm{ab}}$ & $9.73(3.2)^{\mathrm{A}, \mathrm{b}}$ & $11.48(0.7)^{\mathrm{A}, \mathrm{b}}$ & $9.51(2.7)^{\mathrm{A}, \mathrm{b}}$ & $13.32(1.4)^{\mathrm{B}, \mathrm{a}}$ \\
\hline \multicolumn{7}{|c|}{ Middle } \\
\hline MTA & $3.58(0.9)^{\mathrm{B}, \mathrm{b}}$ & $9.15(3.4)^{\mathrm{A}, \mathrm{a}}$ & $3.92(1.3)^{\mathrm{B}, \mathrm{b}}$ & $8.36(1.7)^{\mathrm{A}, \mathrm{a}}$ & $2.74(1.1)^{\mathrm{B}, \mathrm{C}}$ & $8.18(1.7)^{\mathrm{c}, \mathrm{a}}$ \\
\hline Biodentine & $4.88(1.8)^{\mathrm{B}, \mathrm{c}}$ & $8.22(2.9)^{\mathrm{A}, \mathrm{b}}$ & $7.63(3.7)^{\mathrm{A}, \mathrm{b}}$ & $9.39(3.7)^{\mathrm{A}, \mathrm{b}}$ & $10.69(3.2)^{A, b}$ & $13.98(1.9)^{\mathrm{A}, \mathrm{a}}$ \\
\hline Endosequence putty & $8.53(1.2)^{A, b}$ & $10.00(1.6)^{\mathrm{A}, \mathrm{ab}}$ & $8.99(3.1)^{A, b}$ & $8.65(1.9)^{A, b}$ & $9.69(2.0)^{\mathrm{A}, \mathrm{b}}$ & $11.59(2.4)^{\mathrm{B}, \mathrm{a}}$ \\
\hline
\end{tabular}

Abbreviations: $\mathrm{Ca}(\mathrm{OH})_{2}$, calcium hydroxide; DAP, double antibiotic paste; MPa, megapascal; MTA, mineral trioxide aggregate; SD, standard deviation; TAP, triple antibiotic paste.

Different superscript uppercase letters within each treatment group represent significant differences between different types of cements. Different superscript lowercase letters within each cement group represent significant differences between different types of treatments. Note: The uppercase letter ( $A$ and $B$ ) and the lowercase letter ( $a, b$, and $a b$ ) were used to identify that the groups with the same letter are not statistically different from each other, while groups with different letters are statistically different from each other.

\section{Discussion}

High-bond strength of intracanal cement is thought to reflect a better sealing ability of intracanal cements against bacterial leakage. Additionally, bond strength plays an essential role in resisting the dislocation force that may happen indirectly from occlusal functional forces. This study evaluated the effects of low concentrations of TAP and DAP $(1 \mathrm{mg} / \mathrm{mL})$ loaded into an aqueous methylcellulose system on the pushout bond strength of MTA, Biodentine, or Endosequence putty cements. None of the previous studies were able to precisely evaluate the effects of low concentrations of TAP and DAP on push-out bond strength due to the lack of pastelike antibiotic medicaments in low concentrations.

In the present study, $1 \mathrm{mg} / \mathrm{mL}$ DAP showed the highest bond strength compared with all other treatment groups regardless of the cement type. This can be justified by the limited effects of lower concentration of DAP on the chemical and physical properties of radicular dentin. Lower concentration of DAP was proposed to cause significantly less dentin demineralization ${ }^{17,19}$ and surface roughness. ${ }^{17,20}$ These limited effects may minimize the negative effects on the mechanical adhesion and chemical bonding between various cements and dentin. ${ }^{21}$ Furthermore, the excessive loss of calcium and phosphate during dentin demineralization may negatively affect the biomineralization process that is necessary to develop a strong chemical bond between calcium silicate cements and surface dentin..$^{22}$ Although $1 \mathrm{mg} / \mathrm{mL}$ of TAP had resulted in less demineralization ${ }^{8,9,17}$ and surface roughness ${ }^{19,20}$ of the radicular dentin than the typical clinical concentrations of TAP and DAP, the presence of minocycline might negatively affect the bond strength. ${ }^{23}$ The minocycline has strong affinity to chelate calcium in the radicular dentin, which decreases the chemical bonding of calcium silicate-based cements to the radicular dentin. ${ }^{23}$

In general, the push-out bond strength of the intracanal cements in the current study showed that Biodentine and Endosequence putty cements had comparable bond strength and the dominancy of mix and cohesive failures, while MTA cement had significantly lower bond strength and no dominant failure mode. A recent study suggested significantly higher bond strength of Endosequence putty cement compared MTA cement within an acidic environment. ${ }^{24}$ Additionally, multiple recent studies demonstrated that Biodentine had superior bond strength than MTA. ${ }^{11,25-27}$ Nagas et al studied the effects of regular concentration of TAP and $\mathrm{Ca}(\mathrm{OH})_{2}$ on the bond strength of MTA and Biodentine. The study found significantly higher bond strength of Biodentine regardless of the type of medicaments used. ${ }^{28}$ However, in the present study, no significant difference was found in the bond strength between Biodentine and MTA cements with control and $\mathrm{Ca}(\mathrm{OH})_{2}$ groups. The difference in the protocols of the Nagas et al study and the present study may be the cause of different results. However, $1,000 \mathrm{mg} / \mathrm{mL}$ TAP in Nagas et al study as well as in the current study both displayed significantly higher bond strength of Biodentine than MTA. There are three possible explanations of the higher bond strength of Biodentine and Endosequence putty in comparison to MTA reported in the current study. The smaller particles size of Endosequence putty and Biodentine may allow better penetration of the dentinal tubules, which increases the micromechanical retention ${ }^{29,30}$; the ability of Biodentine to form tag-like structures because of high calcium and silicon uptake (Biomineralization) into dentin ${ }^{29}$; finally, the interaction between Biodentine and the radicular dentin may improve water movement (hydration) between the two surfaces, which leads to better penetration of Biodentine into the dentinal tubules. ${ }^{31}$ These three possible reasons can also explain the dominancy of mix and cohesive failures of Biodentine and Endosequence putty cements over MTA cement.

The current study revealed no significant difference in bond strength of Endosequence putty with $1,000 \mathrm{mg} / \mathrm{mL}$ TAP, DAP, and control group. However, both medicaments had higher bond strength than the control when Biodentine was used. In addition, $1,000 \mathrm{mg} / \mathrm{mL}$ DAP had the lowest bond strength with MTA cement. Previous studies that evaluated 
Table 2 Number and percentage of failure mode in each group

\begin{tabular}{|c|c|c|c|c|c|}
\hline Cement & Treatment & Location & $\begin{array}{l}\text { Adhesive } \\
n(\%)\end{array}$ & $\begin{array}{l}\text { Mixed } \\
n(\%)\end{array}$ & $\begin{array}{l}\text { Cohesive } \\
n(\%)\end{array}$ \\
\hline \multirow{12}{*}{ MTA } & \multirow[t]{2}{*}{$\mathrm{Ca}(\mathrm{OH})_{2}$} & Coronal & $3(38 \%)$ & $3(38 \%)$ & $2(25 \%)$ \\
\hline & & Middle & $3(38 \%)$ & $2(25 \%)$ & $3(38 \%)$ \\
\hline & \multirow[t]{2}{*}{ Control } & Coronal & $2(25 \%)$ & $2(25 \%)$ & $4(50 \%)$ \\
\hline & & Middle & $3(38 \%)$ & $2(25 \%)$ & $3(38 \%)$ \\
\hline & \multirow[t]{2}{*}{$1 \mathrm{mg} / \mathrm{mL}$ DAP } & Coronal & $6(75 \%)$ & $0(0 \%)$ & $2(25 \%)$ \\
\hline & & Middle & $0(0 \%)$ & $4(50 \%)$ & $4(50 \%)$ \\
\hline & \multirow[t]{2}{*}{$1,000 \mathrm{mg} / \mathrm{mL}$ DAP } & Coronal & $1(13 \%)$ & $1(13 \%)$ & $6(75 \%)$ \\
\hline & & Middle & $2(25 \%)$ & $3(38 \%)$ & $3(38 \%)$ \\
\hline & \multirow[t]{2}{*}{$1 \mathrm{mg} / \mathrm{mL}$ TAP } & Coronal & $1(13 \%)$ & $3(38 \%)$ & $4(50 \%)$ \\
\hline & & Middle & $4(50 \%)$ & $0(0 \%)$ & $4(50 \%)$ \\
\hline & \multirow[t]{2}{*}{$1,000 \mathrm{mg} / \mathrm{mL}$ TAP } & Coronal & $2(25 \%)$ & $0(0 \%)$ & $6(75 \%)$ \\
\hline & & Middle & $2(25 \%)$ & $4(50 \%)$ & $2(25 \%)$ \\
\hline \multirow{12}{*}{ lodentine } & \multirow[t]{2}{*}{$\mathrm{Ca}(\mathrm{OH})_{2}$} & Coronal & $2(25 \%)$ & $1(13 \%)$ & $5(63 \%)$ \\
\hline & & Middle & $2(25 \%)$ & $3(38 \%)$ & $3(38 \%)$ \\
\hline & \multirow[t]{2}{*}{ Control } & Coronal & $1(13 \%)$ & $1(13 \%)$ & $6(75 \%)$ \\
\hline & & Middle & $4(50 \%)$ & $3(38 \%)$ & $1(13 \%)$ \\
\hline & \multirow[t]{2}{*}{$1 \mathrm{mg} / \mathrm{mL}$ DAP } & Coronal & $1(13 \%)$ & $3(38 \%)$ & $4(50 \%)$ \\
\hline & & Middle & $1(13 \%)$ & $3(38 \%)$ & $4(50 \%)$ \\
\hline & \multirow[t]{2}{*}{$1,000 \mathrm{mg} / \mathrm{mL}$ DAP } & Coronal & $3(38 \%)$ & $0(0 \%)$ & $5(63 \%)$ \\
\hline & & Middle & $2(25 \%)$ & $2(25 \%)$ & $4(50 \%)$ \\
\hline & \multirow[t]{2}{*}{$1 \mathrm{mg} / \mathrm{mL}$ TAP } & Coronal & $3(38 \%)$ & $3(38 \%)$ & $2(25 \%)$ \\
\hline & & Middle & $1(13 \%)$ & $2(25 \%)$ & $5(63 \%)$ \\
\hline & \multirow[t]{2}{*}{$1,000 \mathrm{mg} / \mathrm{mL}$ TAP } & Coronal & $0(0 \%)$ & $4(50 \%)$ & $4(50 \%)$ \\
\hline & & Middle & $3(38 \%)$ & $3(38 \%)$ & $2(25 \%)$ \\
\hline \multirow{12}{*}{ Endosequence putty } & \multirow[t]{2}{*}{$\mathrm{Ca}(\mathrm{OH})_{2}$} & Coronal & $1(13)$ & $3(38 \%)$ & $4(50 \%)$ \\
\hline & & Middle & $4(50)$ & $1(13 \%)$ & $3(38 \%)$ \\
\hline & \multirow[t]{2}{*}{ Control } & Coronal & $1(13 \%)$ & $3(38 \%)$ & $4(50 \%)$ \\
\hline & & Middle & $4(50 \%)$ & $3(38 \%)$ & $1(13 \%)$ \\
\hline & \multirow[t]{2}{*}{$1 \mathrm{mg} / \mathrm{mL}$ DAP } & Coronal & $1(13 \%)$ & $0(0 \%)$ & $7(88 \%)$ \\
\hline & & Middle & $3(38 \%)$ & $1(13 \%)$ & $4(50 \%)$ \\
\hline & \multirow[t]{2}{*}{$1,000 \mathrm{mg} / \mathrm{mL}$ DAP } & Coronal & $1(13 \%)$ & $2(25 \%)$ & $5(63 \%)$ \\
\hline & & Middle & $1(13 \%)$ & $2(25)$ & $5(63)$ \\
\hline & \multirow[t]{2}{*}{$1 \mathrm{mg} / \mathrm{mL}$ TAP } & Coronal & $2(25 \%)$ & $1(13)$ & $5(63)$ \\
\hline & & Middle & $0(0 \%)$ & $4(50)$ & $4(50)$ \\
\hline & \multirow[t]{2}{*}{$1,000 \mathrm{mg} / \mathrm{mL}$ TAP } & Coronal & $2(25 \%)$ & $5(63 \%)$ & $1(13 \%)$ \\
\hline & & Middle & $0(0 \%)$ & $6(75 \%)$ & $2(25 \%)$ \\
\hline
\end{tabular}

Abbreviations: n, number; MTA, mineral trioxide aggregate; $\mathrm{Ca}(\mathrm{OH})_{2}$, calcium; TAP, triple antibiotic paste; DAP, double antibiotic paste.

the bond strength of MTA ${ }^{10,32,33}$ and Endosequence root repair material ${ }^{34}$ with TAP and DAP had similar findings. However, other studies demonstrated no effects on the bond strength of MTA when TAP or DAP was used. ${ }^{28,35} \mathrm{~A}$ recent study found that no medicament control group had the highest bond strength followed by DAP and TAP groups when MTA, Biodentine, and Endosequence putty were used. ${ }^{31}$ Differences in the protocol from the current study might be the reason behind this disagreement. These differences include incubation time of the medicaments, 2-week setting time of the cements and the fact that application of the cement was done after the root cylinders were sectioned. It is worth mentioning that TAP and DAP used in all previously mentioned studies were in the typical clinical concentrations.

In the present study, $\mathrm{Ca}(\mathrm{OH})_{2}$ had the highest bond strength compared with the typical clinical concentration of TAP and DAP as well as to the control regardless of the cement type. Previous studies generally agreed with the present findings for MTA ${ }^{32,33}$ and Endosequence putty. ${ }^{34}$ However, other studies showed no effects on the bond strength of MTA ${ }^{12,28}$ 
and Biodentine ${ }^{28}$ when $\mathrm{Ca}(\mathrm{OH})_{2}$ was used. A recent study concluded that the no medicament control group and the $\mathrm{Ca}(\mathrm{OH})_{2}$-treated dentin had the highest bond strength when Biodentine was used. ${ }^{31}$ The superiority of $\mathrm{Ca}(\mathrm{OH})_{2}$ bond strength compared with the typical clinical concentration of TAP and DAP might be due to less demineralization ${ }^{8,9,17}$ and surface roughness ${ }^{19,20}$ effect on the radicular dentin in addition to the potential positive effect of the residual $\mathrm{Ca}(\mathrm{OH})_{2}$ on the chemical bonding of the calcium silicate-based cements. ${ }^{36}$

This study demonstrated that the coronal cylindrical sections have higher bond strength than the middle cylindrical sections in all treatment groups except for the $1,000 \mathrm{mg} / \mathrm{mL}$ DAP group. A recent meta-regression analysis concluded that apical third sections have lower bond strength than coronal ones. ${ }^{37}$ Another study suggested the existence of regional differences in penetration of sealer cement between apical and coronal areas, where the apical region has the least penetration, and consequently, the bond strength to radicular dentin decreases. ${ }^{38}$ Some possible explanations of the present study's results are that different areas in the root have different dentinal tubule densities, ${ }^{39,40}$ orientations, ${ }^{40}$ or degrees of sclerosis. ${ }^{41}$ In addition, moving apically, the diameter of the dentinal tubule becomes smaller. ${ }^{42}$ However, other previous studies found no significant difference in the bond strength of intracanal cements in different root section locations. ${ }^{11,18}$ The difference in results between the present study and previous ones may be due to different exposure times of the medicaments to radicular dentin or different setting times for the cements before the push-out bond strength test was performed.

The failure mode analysis in the present study generally agreed with previous studies. When $\mathrm{Ca}(\mathrm{OH})_{2}$, no intracanal medicament, and $1,000 \mathrm{mg} / \mathrm{mL}$ TAP where used, cohesive and mixed type failures were higher in MTA, ${ }^{10,11,24,31,33,43}$ Biodentine, ${ }^{11,31}$ and Endosequence putty. ${ }^{31,33,34,43}$ Contrary to the current study, no predominant failure mode was reported when $1,000 \mathrm{mg} / \mathrm{mL}$ DAP was used with the three cements types. ${ }^{10,31,33,34}$ One study reported a predominant adhesive failure with $1,000 \mathrm{mg} / \mathrm{mL}$ DAP for MTA cement. ${ }^{31}$

\section{Conclusion}

Within the limitations of the current study, $1 \mathrm{mg} / \mathrm{mL}$ of DAP loaded into a hydrogel methylcellulose system and $\mathrm{Ca}(\mathrm{OH})_{2}$ did not have a significant negative effect on the bond strength of calcium silicate-based cement to radicular dentin.

\section{Funding}

This study received its financial support from Delta Dental Foundation.

\section{Conflict of Interest}

None declared.

\section{References}

1 Ding RY, Cheung GS, Chen J, Yin XZ, Wang QQ Zhang CF. Pulp revascularization of immature teeth with apical periodontitis: a clinical study. J Endod 2009;35(5):745-749
2 Wigler R, Kaufman AY, Lin S, Steinbock N, Hazan-Molina H, Torneck CD. Revascularization: a treatment for permanent teeth with necrotic pulp and incomplete root development. J Endod 2013;39(3):319-326

3 Chen MY, Chen KL, Chen CA, Tayebaty F, Rosenberg PA, Lin LM. Responses of immature permanent teeth with infected necrotic pulp tissue and apical periodontitis/abscess to revascularization procedures. Int Endod J 2012;45(3):294-305

4 Lovelace TW, Henry MA, Hargreaves KM, Diogenes A. Evaluation of the delivery of mesenchymal stem cells into the root canal space of necrotic immature teeth after clinical regenerative endodontic procedure. J Endod 2011;37(2):133-138

5 Trope M. Treatment of the immature tooth with a non-vital pulp and apical periodontitis. Dent Clin North Am 2010;54(2):313-324

6 AAE. Clinical considerations for a regenerative procedures. American Association of Endodontists. Available at: https:// www.aae.org/specialty/clinical-resources/regenerative-endodontics/. Published 2018. Updated January 4, 2018. Accessed October 13, 2019

7 Ruparel NB, Teixeira FB, Ferraz CC, Diogenes A. Direct effect of intracanal medicaments on survival of stem cells of the apical papilla. J Endod 2012;38(10):1372-1375

8 Yassen GH, Eckert GJ, Platt JA. Effect of intracanal medicaments used in endodontic regeneration procedures on microhardness and chemical structure of dentin. Restor Dent Endod 2015;40(2):104-112

9 Yassen GH, Vail MM, Chu TG, Platt JA. The effect of medicaments used in endodontic regeneration on root fracture and microhardness of radicular dentine. Int Endod J 2013;46(7):688-695

10 Topçuoğlu HS, Arslan H, Akçay M, Saygili G, Çakici F, Topçuoğlu G. The effect of medicaments used in endodontic regeneration technique on the dislocation resistance of mineral trioxide aggregate to root canal dentin.J Endod 2014;40(12):2041-2044

11 El-Ma'aita AM, Qualtrough AJ, Watts DC. The effect of smear layer on the push-out bond strength of root canal calcium silicate cements. Dent Mater 2013;29(7):797-803

12 Turk T, Ozisik B, Aydin B. Time-dependent effectiveness of the intracanal medicaments used for pulp revascularization on the dislocation resistance of MTA. BMC Oral Health 2015;15(1):130

13 Jacobs JC, Troxel A, Ehrlich Y, et al. Antibacterial effects of antimicrobials used in regenerative endodontics against biofilm bacteria obtained from mature and immature teeth with necrotic pulps. J Endod 2017;43(4):575-579

14 McIntyre PW, Wu JL, Kolte R, et al. The antimicrobial properties, cytotoxicity, and differentiation potential of double antibiotic intracanal medicaments loaded into hydrogel system. Clin Oral Investig 2019;23(3):1051-1059

15 Dawood AE, Parashos P, Wong RHK, Reynolds EC, Manton DJ. Calcium silicate-based cements: composition, properties, and clinical applications. J Investig Clin Dent 2017;8(2)

16 Torabinejad M, Parirokh M. Mineral trioxide aggregate: a comprehensive literature review-part II: leakage and biocompatibility investigations. J Endod 2010;36(2):190-202

17 Prather BT, Ehrlich Y, Spolnik K, Platt JA, Yassen GH. Effects of two combinations of triple antibiotic paste used in endodontic regeneration on root microhardness and chemical structure of radicular dentine. J Oral Sci 2014;56(4):245-251

18 Yassen GH, Huang R, Al-Zain A, Yoshida T, Gregory RL, Platt JA. Evaluation of selected properties of a new root repair cement containing surface pre-reacted glass ionomer fillers. Clin Oral Investig 2016;20(8):2139-2148

19 Yassen GH, Sabrah AH, Eckert GJ, Platt JA. Effect of different endodontic regeneration protocols on wettability, roughness, and chemical composition of surface dentin. J Endod 2015;41(6):956-960 
20 Nerness AZ, Ehrlich Y, Spolnik K, Platt JA, Yassen GH. Effect of triple antibiotic paste with or without ethylenediaminetetraacetic acid on surface loss and surface roughness of radicular dentine. Odontology 2016;104(2):170-175

21 Sarkar NK, Caicedo R, Ritwik P, Moiseyeva R, Kawashima I. Physicochemical basis of the biologic properties of mineral trioxide aggregate. J Endod 2005;31(2):97-100

22 Reyes-Carmona JF, Felippe MS, Felippe WT. The biomineralization ability of mineral trioxide aggregate and Portland cement on dentin enhances the push-out strength. J Endod 2010;36(2):286-291

23 Minabe M, Takeuchi K, Kumada H, Umemoto T. The effect of root conditioning with minocycline $\mathrm{HCl}$ in removing endotoxin from the roots of periodontally-involved teeth. J Periodontol 1994;65(5):387-392

24 Shokouhinejad N, Yazdi KA, Nekoofar MH, Matmir S, Khoshkhounejad M. Effect of acidic environment on dislocation resistance of endosequence root repair material and mineral trioxide aggregate. J Dent (Tehran) 2014;11(2):161-166

25 Guneser MB, Akbulut MB, Eldeniz AU. Effect of various endodontic irrigants on the push-out bond strength of biodentine and conventional root perforation repair materials. J Endod 2013;39(3):380-384

26 Lucas CP, Viapiana R, Bosso-Martelo R, Guerreiro-Tanomaru JM, Camilleri J, Tanomaru-Filho M. Physicochemical properties and dentin bond strength of a tricalcium silicate-based retrograde material. Braz Dent J 2017;28(1):51-56

27 Akcay H, Arslan H, Akcay M, Mese M, Sahin NN. Evaluation of the bond strength of root-end placed mineral trioxide aggregate and Biodentine in the absence/presence of blood contamination. Eur J Dent 2016;10(3):370-375

28 Nagas E, Cehreli ZC, Uyanik MO, Vallittu PK, Lassila LV. Effect of several intracanal medicaments on the push-out bond strength of ProRoot MTA and Biodentine. Int Endod J 2016;49(2):184-188

29 Han L, Okiji T. Uptake of calcium and silicon released from calcium silicate-based endodontic materials into root canal dentine. Int Endod J 2011;44(12):1081-1087

30 Camilleri J, Sorrentino F, Damidot D. Investigation of the hydration and bioactivity of radiopacified tricalcium silicate cement, Biodentine and MTA Angelus. Dent Mater 2013;29(5): 580-593

31 Aydin MN, Buldur B. The effect of intracanal placement of various medicaments on the bond strength of three calcium silicate-based cements to root canal dentin. J Adhes Sci Technol 2017;32(5):542-552

32 Patil U, Yeli M, Tapashetti S, Naik B, Tilakchand M. Effect of varying durations of intracanal medicament application used in regenerative endodontic treatment on the push-out bond strength of a novel cement: NeoMTA Plus. J Conserv Dent 2019;22(1):48-53

33 Amin SAW, Gawdat SI. Retention of BioAggregate and MTA as coronal plugs after intracanal medication for regenerative endodontic procedures: an ex vivo study. Restor Dent Endod 2018;43(3):e18

34 Oktay EA, Ersahan S, Gokyay S. Effect of intracanal medicaments used in endodontic regeneration on the push-out bond strength of a calcium-phosphate-silicate-based cement to dentin. Pak J Med Sci 2018;34(2):310-315

35 Gokturk H, Bayram E, Bayram HM, Aslan T, Ustun Y. Effect of double antibiotic and calcium hydroxide pastes on dislodgement resistance of an epoxy resin-based and two calcium silicate-based root canal sealers. Clin Oral Investig 2017;21(4):1277-1282

36 Bidar M, Disfani R, Gharagozloo S, Khoynezhad S, Rouhani A. Medication with calcium hydroxide improved marginal adaptation of mineral trioxide aggregate apical barrier. J Endod 2010;36(10):1679-1682

37 Collares FM, Portella FF, Rodrigues SB, Celeste RK, Leitune VCB, Samuel SMW. The influence of methodological variables on the push-out resistance to dislodgement of root filling materials: a meta-regression analysis. Int Endod J 2016;49(9):836-849

38 Weis MV, Parashos P, Messer HH. Effect of obturation technique on sealer cement thickness and dentinal tubule penetration. Int Endod J 2004;37(10):653-663

39 Mannocci F, Pilecki P, Bertelli E, Watson TF. Density of dentinal tubules affects the tensile strength of root dentin. Dent Mater 2004;20(3):293-296

40 Ferrari M, Mannocci F, Vichi A, Cagidiaco MC, Mjör IA. Bonding to root canal: structural characteristics of the substrate. Am J Dent 2000;13(5):255-260

41 Paqué F, Luder HU, Sener B, Zehnder M. Tubular sclerosis rather than the smear layer impedes dye penetration into the dentine of endodontically instrumented root canals. Int Endod J 2006;39(1):18-25

42 Marion D, Jean A, Hamel H, Kerebel LM, Kerebel B. Scanning electron microscopic study of odontoblasts and circumpulpal dentin in a human tooth. Oral Surg Oral Med Oral Pathol 1991;72(4):473-478

43 Alsubait S, Alsaad N, Alahmari S, Alfaraj F, Alfawaz H, Alqedairi A. The effect of intracanal medicaments used in Endodontics on the dislocation resistance of two calcium silicate-based filling materials. BMC Oral Health 2020;20(1):57 